\title{
The Influence of Heregulins on Human Schwann Cell Proliferation
}

\author{
Allan D. O. Levi,' Richard P. Bunge, ${ }^{1}$ Julie A. Lofgren, ${ }^{2}$ Leonie Meima, ${ }^{2}$ Franz Hefti, ${ }^{2}$ Karoly Nikolics, ${ }^{2}$ \\ and Mark X. Sliwkowski² \\ 'The Miami Project to Cure Paralysis and the Department of Neurological Surgery, University of Miami School of \\ Medicine, Miami, Florida 33136 and ${ }^{2}$ Genentech Inc., South San Francisco, California 94080
}

The use of Schwann cell (SC) autotransplantation to influence neural repair in humans is dependent upon identifying mitogens that will effectively expand human Schwann cells (SCs) in culture. The recent purification and molecular cloning of glial growth factor (GGF), a potent mitogen for rat Schwann cells, has led to the recognition that a family of proteins (GGF/HRG/NDF/ARIA) are alternatively spliced products of a single gene. The heregulins (HRGs) have been characterized with respect to their influence on human breast cancer cell lines; here we examined whether the HRGs have mitogenic activity for human SCs. Using DNA synthesis assays and serial passaging of cells in culture, we demonstrate that HRG is an effective mitogen for human SCs and that, in the presence of agents that elevate CAMP, it is possible to expand these cells over multiple passages without overwhelming fibroblast contamination.

One putative target for this family of proteins is p185 ${ }^{\text {erbez }}$, an EGF-like receptor tyrosine kinase that is encoded by the erbB2 protooncogene. In this report we also demonstrate that the erbB2/3/4 messages as well as the erbB2/3 receptor proteins are present within cultured human SCs. The addition of HRG to human SCs results in tyrosine phosphorylation of a $185 \mathrm{kDa}$ protein. In the presence of stimulatory concentrations of HRG, a blocking monoclonal antibody (2C4) to p185 erbe2 is capable of significantly inhibiting phosphorylation of a $185 \mathrm{kDa}$ protein as well as the subsequent incorporation of ${ }^{3} \mathrm{H}$-thymidine within the human $\mathrm{SC}$. These latter

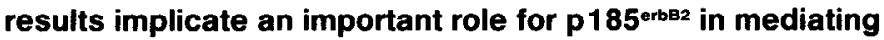
the mitogenic response of human SCs to HRGs.

[Key words: Schwann cells, human, heregulin, erbB2 receptor, proliferation, CAMPJ

\footnotetext{
Received Mar. 21, 1994; revised Aug. 2, 1994; accepted Aug. 10, 1994

This work was supported by NIH/NINDS Grant NS09923, National MS Society Grant RG 2210-A.2, Gliatech Inc., and The Miami Project to Cure Paralysis. A.D.O.L. is a fellow of the Medical Research Council of Canada. We acknowledge the collaboration of T. K. Morrissey and R. Soriano. We thank Lisa Gwynn and Leeanne Lipson for their excellent technical assistance. We also thank Dr. J. Klose for assisting with the statistical analysis; N. Abadi, R. Hayes, and H. Heinsohn for assistance with the rHRG $\beta 1_{177244}$ purification; Dr. R. Cerione, Cornell University, for insect cells expressing erbB3; B. Fendly and W. L. Wong for erbB2 and erbB3 antibodies; and Les Olson, J. D. Waters, and the University of Miami transplant team for obtaining the human tissues. By their generosity and compassion, organ donors and their families have made this study possible.

Correspondence should be addressed to Dr. R. Bunge, The Miami Project, University of Miami School of Medicine, 1600 NW 10th Avenue, R-48, Miami, FL 33136.

Copyright (C) 1995 Society for Neuroscience $0270-6474 / 95 / 151329-12 \$ 05.00 / 0$
}

Schwann cells (SCs) are the principal support cells throughout the PNS, providing each axon with either ensheathment or a series of myelin segments. SCs originate from neural crest tissue early in embryonic development (Zimmer and Le Dourain, 1993) and migrate into the periphery along with growing axons. During this time, they undergo rapid cell division (Asbury, 1967) to accommodate an increasing number of peripheral axons (Lemke, 1990). As they undergo their final differentiation, they stop dividing and remain essentially quiescent for the remainder of the life of the animal (Asbury, 1967). Under pathological conditions such as peripheral nerve injury, demyelination, and tumorigenesis, the SC can be reactivated to enter the cell cycle (De Vries, 1993).

SCs produce a number of factors that are known to promote axonal regeneration. These include several well-characterized neurotrophic factors (Heumann et al., 1987; Acheson et al., 1991; Friedman et al., 1992), cell adhesion molecules (Daniloff et al., 1986; Bixby et al., 1988), and basement membrane components (Bunge and Bunge, 1983). SCs have a remarkable capacity to promote nerve fiber regeneration in both the PNS (Nadim et al., 1988; Guénard et al., 1992) and the CNS (David and Aguayo, 1981; Paino and Bunge, 1991; Guénard et al., 1993). The construction of cellular prostheses consisting of human SCs could conceivably have several therapeutic applications in the repair of neural injuries.

The use of cell culture techniques to obtain an abundant source of autologous graft material from a small biopsy has been an approach that has already met with clinical success in providing human epidermal cells to cover extensive burns (Green et al., 1979; Gallico et al., 1984). The construction of an autologous cellular prosthesis from human SCs is dependent upon the ability to obtain purified populations of SCs from adult peripheral nerve (Morrissey et al., 1991a) and to expand such cells in culture. As many agents that are effective for rat $\mathrm{SC}$ proliferation are minimally effective in inducing human SCs to divide (Morrissey et al., 1991a,b), a central goal of our research has been to identify mitogens that are effective in specifically promoting human SC proliferation.

The purification of multiple forms of glial growth factor (GGF; Goodearl et al., 1993), which are potent mitogens for SCs (Lemke and Brockes, 1984), has allowed for the molecular cloning of this protein (Marchionni et al., 1993). Genomic sequence analysis of GGF, as well as members of a number of recently characterized families of proteins [heregulins (HRG), Holmes et al., 1992; neu differentiation factor (NDF), Wen et al., 1992; and ACh receptor inducing activity (ARIA), Falls et al., 1993], has rapidly led to the recognition that these proteins represent a 
family of alternatively spliced products of the same gene (Lemke, 1993). The availability of human recombinant proteins (HRGs; Holmes et al., 1992) with similar sequences and receptor activation profiles as the newly characterized GGFs (Goodearl et al., 1993; Marchionni et al., 1993) led us to test the influence of purified recombinant $\mathrm{HRG}$ s on human $\mathrm{SC}$ proliferation

Among the observations we report here are (1) a recombinant protein, HRG $\beta 1$ (residues 177-244), which contains the epidermal growth factor (EGF)-like domain of heregulin $\beta 1$, is a potent mitogen for human SCs; (2) expansion of human SCs without overwhelming fibroblast contamination has been possible only when activators of adenyl cyclase are added to $\mathrm{rHRG}$ $\beta 1_{177-244}$; and (3) the $\mathrm{p} 185^{\mathrm{erbB} 2}$ receptor message and protein are present in human SCs and appear to be important in mediating the mitogenic effects of rHRG $\beta 1_{177-244}$ on human SCs.

\section{Materials and Methods}

Preparation of purified human Schwann cell cultures. Human peripheral nerves were obtained from urgan donors (14 months to 63 years; $n=$ $15)$ by the transplant procurement team of the University of Miami School of Medicine. The nerves were used for subsequent study if the donors had a negative serology for infectious agents and if their past medical history was ncgative for any discases predisposing to a peripheral neuropathy. The nerves (phrenic, intercostal, or lumbosacral plexus) were harvested within 30 min of aortic clamping and stored in RPMI (GIBCO Laboratories, Grand Island, NY) at $4^{\circ} \mathrm{C}$ for no more than 24 hr. Each peripheral nerve was prepared for culture according to the protocol of Morrissey et al. (1991a). This includes washing the nerve three times in Liebovitz's L15 (GIBCO), stripping the epineurium of the nerve, and removing individual fascicles from the remaining interfascicular epineurium. The fascicles were cut into explants $2-4 \mathrm{~mm}$ long and 6-10 explants were placed in $35 \mathrm{~mm}$ culture dishes. The prepared nerves were kept in a humidified atmosphere with $5 \% \mathrm{CO}_{2}$ and the medium was replaced twice per week with Dulbecco's Modified Eagle's Medium (DMEM; GIBCO) with 10\% fetal calf serum (FCS). The individual explants were transplanted to new dishes after a confluent monolayer of predominantly fibroblasts ( $\mathrm{Fbs}$ ) had becn generated as an outgrowth. This occurred in approximately 7-14 $\mathrm{d}$.

After one to three transplantations the nerve explants were dissociated according to the protocol of Pleasure et al. (1986). In brief, multiple explants were pooled and placed in 1-2 $\mathrm{ml}$ of an enzyme cocktail consisting of $1.25 \mathrm{U} / \mathrm{ml}$ dispase (Boehringer Mannheim Biochemicals, Germany), $0.05 \%$ collagenase (Worthington Biochemicals Corp., Freehold, $\mathrm{NJ}$ ) and $15 \%$ FCS in DMEM. The explants were left in enzymes overnight and gently triturated the following morning with a straight glass borosilicate pipette, until individual explants could no longer be recognized. The cells were then washed in L15 and 10\% FCS and plated on $100 \mathrm{~mm}$ culture dishes coated with $200 \mu \mathrm{m} / \mathrm{ml}$ poly-L-lysine (PLL; Sigma, St. Louis, MO).

The following day the cells were taken off the PLL-coated culture plates by rinsing twice with $\mathrm{Ca}^{3+}$ and $\mathrm{Mg}^{3+}$-frce Hanks Balanced Salt Solution (HBSS; GIBCO) and exposing them to trypsin $(0.05 \%)$ and EDTA $(0.02 \%)$ (Sigma) in HBSS for $5-10 \mathrm{~min}$ at $37^{\circ} \mathrm{C}$. The cells were collected and rinsed twice in L15 and $10 \%$ FCS, counted on a hemocytometer, and then diluted into a calculated volume of DMEM and $10 \%$ FCS (D10). The cells were then seeded on Aclar (Allied Fiber and Plastics, Pottsville, PA) mini dishes coated with ammoniated collagen or PLL-coated culture dishes for subsequent study.

Human Schwann cell and fibroblast labeling indices. The central portions of mini dishes (see above) were seeded with $25-50,000$ cells. The following day they were flooded with media containing D10 in the absence or presence of specified concentrations of mitogens [the truncated form of recombinant heregulin $\beta 1$ (rHRG $\beta 1_{177-244}$ ) or full-length recombinant heregulin $\beta 1$ (Genentech, South San Francisco, CA); cholera toxin (CT; Sigma, St. Louis, MO); forskolin (Sigma)]. After $48 \mathrm{hr}$ the same medium plus ${ }^{3} \mathrm{H}$-thymidine $(0.5 \mu \mathrm{Ci} / \mathrm{ml})$ was added for exactly $24 \mathrm{hr}$ to label nuclei that were synthesizing DNA. In some experiments, longer ( 48 or $72 \mathrm{hr}$ ) pulses of ${ }^{3} \mathrm{H}$-thymidine $(0.1 \mu \mathrm{Ci} / \mathrm{ml})$ were added to the cultures to determine if the population of human SCs under analysis was relatively homogeneous in their ability to respond to the added mitogens (rHRG $\beta 1_{177.244}$, cholera toxin, and forskolin).

The cells were rinsed thoroughly with $\mathrm{L} 15$ to remove the radioactive medium and then fixed in $4 \%$ paraformaldehyde and permeabilized in $4 \%$ paraformaldehyde containing $0.03 \%$ Triton-X 100 . The cultures were then blocked with $10 \%$ goat serum in $\mathrm{L} 15$ and then incubated with anti-S100 antibody (1:100; Dakopatts, Denmark) for $45 \mathrm{~min}$, washed with L15, and incubated with a rhodamine-conjugated goat anti-rabbit secondary antibody (1:50; Cappel/Organon, Teknika Corp., West Chester, PA) for 35 min. The cultures were mounted tissue side up on glass slides with DPX mountant (BDH Laboratory, England), dipped in emulsion (Kodak emulsion NTB 2, Rochester, NY), stored at $4^{\circ} \mathrm{C}$ for $5 \mathrm{~d}$, and then processed for autoradiographic development. A coverslip was applied to the cultures after adding a drop of a glycerol/phosphatebuffered saline solution (Citifluor Ltd., London, UK) containing $5 \mu \mathrm{M}$ Hoechst dye (Hoechst 33342, Sigma). The Hoechst dye binds DNA and was used to image all the nuclei within the culture under the fluorescence microscope.

Human SCs were identified as S100 and Hoechst positive; Fbs appeared as pleomorphic flat cells that were Hoechst positive but $\$ 100$ negative. The number of SCs and Fbs whose nuclei were labeled by autoradiographic grains was counted relative to the total number of these cells on 20 random fields for each sample (no less than 250 cells/ slide).

Expansion of human Schwann cells in culture. Human cells that had been dissociated from explants of adult peripheral nerve (see above) were seeded on PLL-coated dishes and were exposed to media containing D10 with either $\mathrm{rHRG} \beta 1_{177-244}(10 \mathrm{nM})$ alone or the triple mitogen cocktail consisting of $\mathrm{rHRG} \beta 1_{177-244}(10 \mathrm{nM})$, CT $(100 \mathrm{ng} / \mathrm{ml})$, and forskolin $(1 \mu \mathrm{M})$. The initial sceding of cells onto culturc plates is referred to as passage $0(\mathrm{P} 0)$. The initial SC purity was also determined by seeding the dissociated cells onto a collagen-coated mini dish and immunostaining the cells for $\mathrm{S} 100$. The medium was changed three times per week and when the cells had reached confluency, they were taken up from the culture dishes with the trypsin $(0.05 \%) / \operatorname{EDTA}(0.02 \%)$ solution. The cells were collected, counted on a hemocytometer, and then split in half by seeding the cells onto two PLL-coated culture plates. At each passage a small aliquot of cells $(<10,000)$ was also seeded on a collagen-coated mini dish and immunostained for $\mathrm{S} 100$ (see above) to determine the SC purity for that passage. The cells that had been split were again exposed to the above-described mitogens and processed in the same way when they had reached confluency.

Analysis of erbB2/3/4 expression in human Schwann cells. PolyA RNA was prepared from human SCs $\left(1 \times 10^{6}\right)$, which wcre previously expanded on the triple mitogens, using the Micro-Fast Track mRNA isolation kit (Invitrogen, San Diego, CA). RT-PCR reactions were performed with specific primer combinations for erbB2, erbB3, and erbB4 in a Perkin-Elmer 9600 instrument using reagents of the cDNA cycle kit (Invitrogen), and the PCR products were analyzed by gel electrophoresis. The gels were blotted onto nylon membranes, which were hybridized with internal oligonucleotide probes corresponding to the individual receptor proteins. This dual probing strategy (unique primer combinations and unique internal nucleotide probes) provided a high degree for specificity of this analysis. The probed blots were analyzed in a Fuji BAS Biolmage Analyzer (Fuji Photo Film Co, Japan) image analysis system and the printouts of these screens are shown.

The primers used for erbB2 were, for upper, 5' AGGGAAACCTGGAACTCACC 3'; lower, 5' TGGATCAAGACCCCTCCTTT 3'. The internal nucleotide probe was $5^{\prime}$ GTGGGACCTGCCTCACTTGG 3'. The amplified fragment size was 298 base pairs (bp). The primers used for erbB3 were, for upper, 5' CAGGTGCTGGGCTTGCTTTT 3'; lower, 5' GTGGCTGGAGTTGGTGTTAT 3'. The internal nucleotide probe was $5^{\prime}$ CACTGTACAAGCTCTACGAGAGGTGTGAGGTGGTGATGGG 3'. The amplified fragment size was 366 bp. The primers used for erbB4 were, for upper, 5' TCCAGCCCAGCGATTCTCAG 3'; lower, 5' GGCCAGTACAGGACTTATGG $3^{\prime}$. The internal nucleotide probe was $5^{\prime} \mathrm{TG}$ GAAACTTTGGACTTCAAGAACTTGGATTAAAGAAGTTG $3^{\prime}$. The amplified fragment size was $495 \mathrm{bp}$.

Western blot analysis. SCs were removed from tissue culture flasks using $2 \mathrm{~mm}$ EDTA in phosphate-buffered saline and gentle scraping. Harvested cells werc pelleted by low-speed centrifugation, resuspended in buffer, and then counted using a hemocytometer. Cells were then repelleted and suspended in SDS-PAGE sample buffer. Samples for SDS-PAGE analysis were prepared such that the equivalent of $8 \times 10^{4}$ cells per lane were loaded onto precast 4-12\% gradient gels from Novex (San Diego, CA). The SDS gels were then electroblotted onto nitrocellulose. The nitrocellulose was blocked using $2 \%$ bovine serum albumin (BSA) in $25 \mathrm{~mm}$ Tris $\mathrm{HCl}$ buffer, $\mathrm{pH} 7.5$, with $0.3 \mathrm{M} \mathrm{NaCl}$ and $0.5 \%$ 


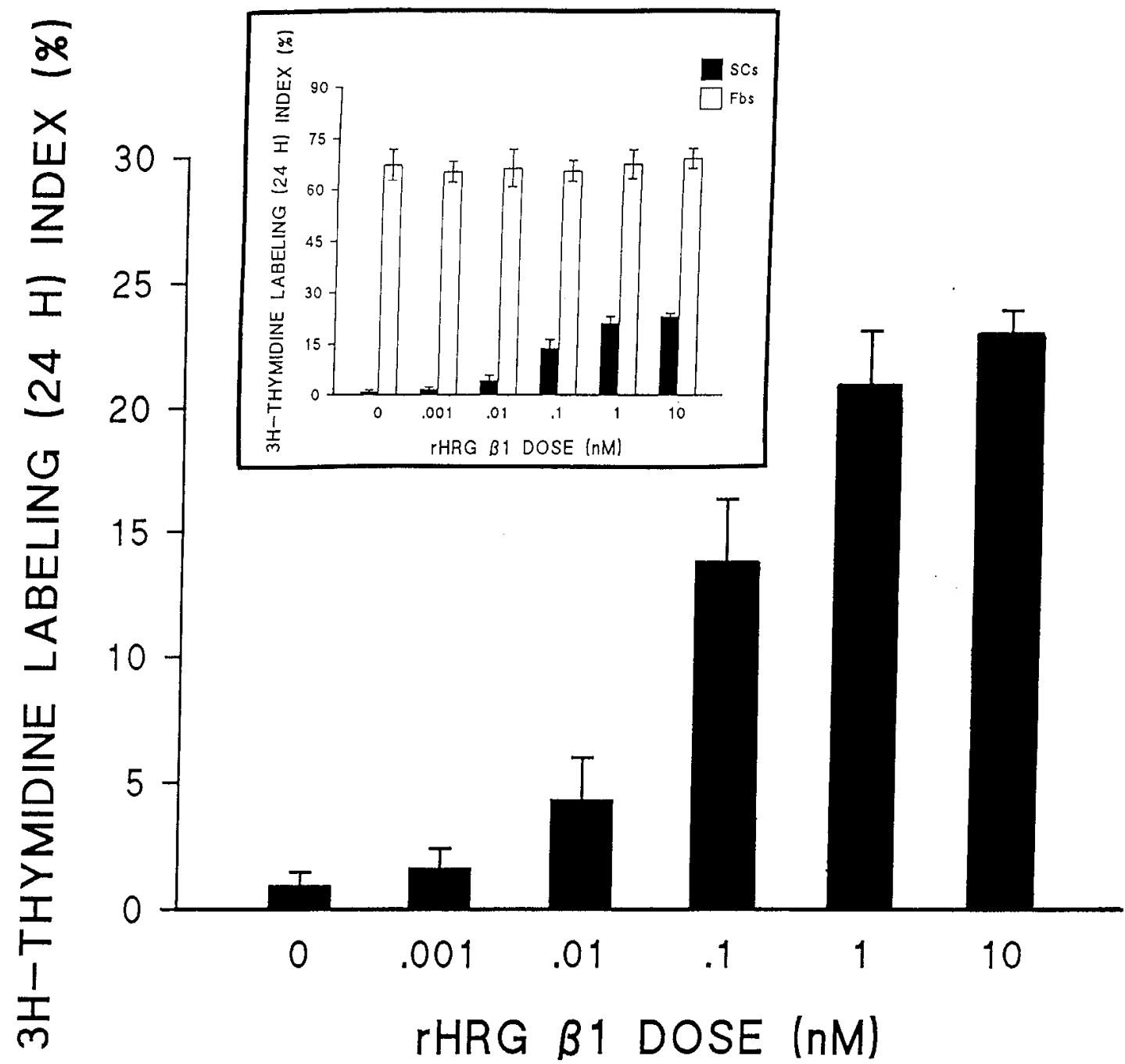

Figure 1. Dose (0-10 nM) response of heregulin (rHRG $\left.\beta 1_{177-244}\right)$ on human SC labeling index ( $24 \mathrm{hr}$ ). Inset, Dose response of rHRG $\beta 1_{177-244}$ on both human $\mathrm{SC}$ and $\mathrm{Fb}$ labeling index. rHRG $\beta 1_{177-244}$ significantly increases SC labeling index with increasing doses $(p<0.01)$. It has no effect on $\mathrm{Fb}$ labeling index, but baseline $\mathrm{Fb}$ labeling under serum containing conditions (10\% FCS) is substantially higher than even the highest SC labeling index observed with added rHRG $\beta \mathbf{I}_{177-244}(10 \mathrm{nM})$. The experiment was repeated with five different donors $(n=5)$ whose average age was 19 years.

Tween-20. Blots were probed with an affinity-purified rabbit polyclonal to the extracellular domain (ECD) of the erbB2 protein (Fendly et al., 1990a) at a final concentration of $0.8 \mu \mathrm{g} / \mathrm{ml}$ or an anti-erbB3 rabbit polyclonal antibody (Transduction Laboratories, Lexington, KY) used at a concentration of $0.25 \mu \mathrm{g} / \mathrm{ml}$. Immunoreactive bands were visualized after incubation with horseradish peroxidase-conjugated secondary (antirabbit; Tago, Burlingame, $C A$ ) antibody at a dilution of 1:10,000 for erbB2 blots and 1:2000 for erbB3 blots using enhanced chemiluminescence with reagents obtained from Amersham (Buckinghamshire, England).

Tyrosine phosphorylation assays. Heregulin-stimulated phosphorylation assays using intact expanded human SCs were performed essentially as described by Holmes et al. (1992) with the following modifications. SCs were harvested as described above and resuspended in F12 $(50 \%) / D M E M(50 \%)$ containing $0.1 \%$ BSA. Cells were preincubated for $30 \mathrm{~min}$ at room temperature with $100 \mathrm{nM}$ anti-p $185^{\text {erbB2 }}$ antibody (Fendly et al., 1990b), 2C4 or $2 \mathrm{H} 11$ (Genentech), or a control buffer solution. Incubations with $\mathrm{rHRG} \beta 1_{177-244}$ were then performed for an additional $8 \mathrm{~min}$ at room tempcraturc. Reactions were terminated by the addition of SDS sample buffer. Samples (equivalent of $6 \times 10^{4}$ cells per lane) for SDS-PAGE were loaded onto gradient gels and electroblotted onto nitrocellulose as described above. Blots were probed with anti-phosphotyrosine monoclonal antibody-horseradish peroxidase conjugate (Transduction Laboratories) and immunoreactive bands were visualized as described above.

Blocking $r H R G \beta 1_{177-244}$ mitogenic signaling of human Schwann cells with an anti-p185 ${ }^{\text {ernBz }}$ antibody. Mini dishes containing 25-30,000 cells obtained from primary dissociations of human peripheral nerve were fed with media containing D10 alone or D10 with the monoclonal antibodies $2 \mathrm{C} 4$ or $2 \mathrm{Hll}$ at a concentration of $100 \mathrm{nM}$ for $30 \mathrm{~min}$ at room temperature. Without rinsing the cultures they were then fed with $10 \mathrm{nM}$ rHRG $\beta 1_{177-244}(1 / 10 \mathrm{vol})$ to give a final concentration of $1 \mathrm{~nm}$. The cells were maintained at $37^{\circ} \mathrm{C}$ in $5 \% \mathrm{CO}_{2}$ for an additional $48 \mathrm{hr}$. Cells were pulse labeled for the subsequent $24 \mathrm{hr}$ using media containing ${ }^{3} \mathrm{H}$-thymidine $(0.5 \mu \mathrm{Ci} / \mathrm{ml})$ after reapplying the antibodies (100 $\left.\mathrm{nM}\right)$ followed by rHRG $\beta 1_{177-244}(1 \mathrm{nM})$ as described above. The cells were then fixed and immunostained for S100. The proportion of SCs and Fbs (S100 negative cells) labeled for each condition was determined.

Statistical analysis. The data are presented either as the means \pm SEM (figures) or the means \pm SD (text and Table 1). The data were subjected to an analysis of variance. A commercially available software program, statistica (StatSoft Inc., Tulsa, OK), was used for all statistical analysis.

\section{Results}

Recombinant heregulin stimulates the proliferation of human Schwann cells

Human SCs placed in culture without mitogens (D10) have an extremely low labeling index (Fig. 1). The addition of $r H R G$ $\beta 1_{177-244}$ to the cultures serves as a potent mitogen for the human 


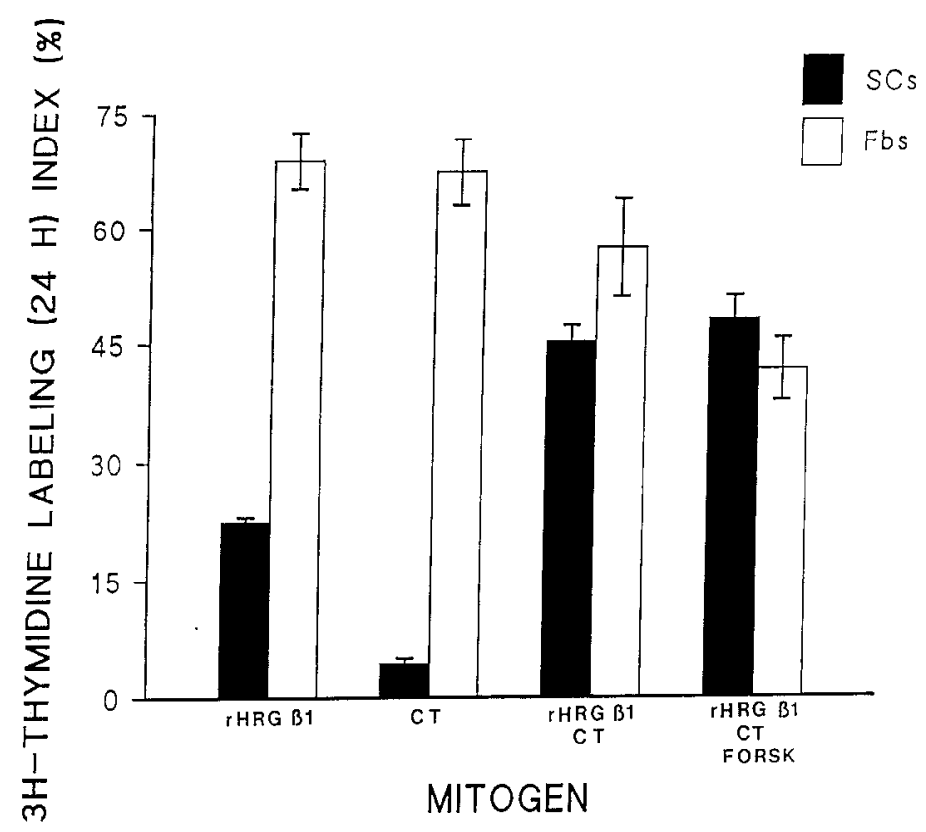

Figure 2. The influence of activators of adenyl cyclase [cholera toxin $(C T), 100 \mathrm{ng} / \mathrm{ml}$; forskolin $(F O R S K), 1 \mu \mathrm{m}$ ) on the heregulin (rHRG $\beta 1_{177-244} ; 10 \mathrm{nM}$ )-activated response of SCs and $\Gamma \mathrm{bs}$. There is a synergistic effect of CT on rHRG $\beta 1_{177-244}$-induced SC labeling $(p<0.01)$. The addition of forskolin to the rHRG $\beta 1_{177-244} / C T$ mitogens significantly reduces $\mathrm{Fb}$ labeling $\left(p<0.01\right.$ ), when compared to rHRG $\beta 1_{177-244}$ alone, to a level in which $\mathrm{SC}$ labeling parallels the $\mathrm{Fb}$ labeling index. The experiment was repeated with four different donors $(n=4)$ whose average age was 15 years.

SC. SC labeling, as measured by ${ }^{3} \mathrm{H}$-thymidine incorporation between 48 and $72 \mathrm{hr}$ after exposure to this mitogen, increases with increasing concentrations of rHRG $\beta 1_{177-244}$ in a dose-related manner. The lowest concentration in which a significant cffect on SC labeling is seen is at 100 pM $(p<0.01)$, and the highest labeling at $10 \mathrm{~nm}$. No further increase in SC labeling was observed at doses of $100 \mathrm{~nm}$ (data not shown). The effective concentrations of rHRG $\beta 1_{177-244}$ on human SC labeling are similar to those concentrations that are effective for proliferation and tyrosine phosphorylation of human breast cancer cell lines (Holmes et al., 1992). The data presented in Figure 1 were generated using a recombinant form of HRG $\beta 1$ that encompasses the EGF-like domain of the protein $(\sim 7.9 \mathrm{kDa})$ and is designated rHRG $\beta 1_{177-244}$. Similar experiments performed with purified full-length recombinant HRG $\beta 1$ (residues 1-244, 45 $\mathrm{kDa}$ ) expressed in mammalian cells had a nearly identical effect on human SC labeling indices (data not shown).

All assays are done in the presence of $10 \%$ FCS (D10) and consequently the labeling of Fbs (Fig. 1, inset) is high (50-80 $\%$ ) and is unaffected by the addition of rHRG $\beta 1_{177-244}$. More importantly, the highest concentration of $\mathrm{HRG} \beta 1_{177-244}(10 \mathrm{nM})$, in the presence of $10 \% \mathrm{FCS}$, results in an SC labeling index that is well below the $\mathrm{Fb}$ labeling index. The high labeling index seen with Fbs occurs because FCS contains a number of factors (Pastan et al., 1975; Olivera and Spiegel, 1993), such as plateletderived growth factor (PDGF), that are known to be potent mitogens for Fbs and Fb cell lines (Heldin et al., 1989). The presence of serum in the culture media also appcars to bc an important requirement for all of the soluble SC mitogens [GGF, Raff et al., 1978a; but see Morgan et al., 1991; Schubert, 1992; transforming growth factor (TGF) $\beta 1$, Schubert, 1992; CT, for-
Table 1. Synergy between heregulin and forskolin in inducing human Schwann cell division

\begin{tabular}{lcc} 
& \multicolumn{2}{l}{$\begin{array}{l}\text { Results } \\
(n=3 \text { donors })\end{array}$} \\
\cline { 2 - 3 } Mitogen & SCs & Fbs \\
\hline D10 & $1.2 \pm 0.8$ & $76.7 \pm 6.9$ \\
FORSK & $2.5 \pm 1.7$ & $71.9 \pm 1.9$ \\
HRG & $22.7 \pm 4.7$ & $75 \pm 3.7$ \\
HRG + FORSK & $47.5 \pm 8.9$ & $69.8 \pm 12.1$ \\
HRG + CT & $51.1 \pm 9.9$ & $74.3 \pm 4.0$
\end{tabular}

Mean Schwann cell and fibroblast labeling indices (24 hr) \pm SD are presented. SCs, Schwann cells; Fbs, fibroblasts; D10, DMEM + 10\% FCS; FORSK, forskolin $(1 \mu \mathrm{M})$; HRG, rHRG $\beta 1_{177-244}(10 \mathrm{nM})$; CT, cholera toxin $(100 \mathrm{ng} / \mathrm{ml})$.

skolin, PDGF, and fibroblast growth factor (FGF), Davis and Stroobant, 1990; Morgan et al., 1991; for a review, see De Vries, 1993[.

\section{Heregulin synergizes with activators of adenyl cyclase to promote Schwann cell proliferation}

Although rHRG $\beta 1_{177-244}$ appeared to be a potent mitogen for human SCs, we tested whether the addition of activators of adenyl cyclase might enhance this effect. As shown in Figure 2, CT alone had a marginal effect on the SC labeling index relative to $\mathrm{rHRG} \beta 1_{177-244}$. However when $\mathrm{rHRG} \beta 1_{177-244}$ and CT were added together, they had a synergistic effect on the human SC labeling index $(p<0.01)$ when compared to either agent alone. When forskolin, another activator of adenyl cyclase, was added to this combination of mitogens, no further increase in the SC labeling index was observed; however, $\mathrm{Fb}$ labeling was significantly inhibited $(p<0.01)$ when compared to the Fb labeling observed in the absence of any activators of adenyl cyclase. In a separate series of experiments (Table 1) the combination of rHRG $\beta 1_{177-244}$ and forskolin was also found to act in synergy to augment the ${ }^{3} \mathrm{H}$-thymidine labeling index of human SCs.

The procedure that has been described to isolate large numbers of SCs from adult peripheral nerve (Morrissey et al., 1991a) invariably yields some Fbs. The inability to differentiate the human $\mathrm{SC}$ from the human $\mathrm{Fb}$ by morphologic criteria alone necessitates that we investigate any potential $\mathrm{SC}$ mitogen by combining ${ }^{3} \mathrm{H}$-thymidine autoradiography with immunostaining for a specific SC antigen (S100). Figure $3 a-d$ contrasts the SC labeling index seen with $\mathrm{rHRG} \beta 1_{177-244}$ alone $(a, c)$ compared to the SC labeling index observed when rHRG $\beta 1_{177-244} / \mathrm{CT} /$ forskolin are added $(b, d)$. SCs are $\mathrm{S} 100$ positive $(c, d)$, and those SCs that have passed through at least a portion of the $S$ phase of the cell cycle during the $24 \mathrm{hr}$ labeling period contain numerous grains over their nuclei $(a, b)$ when the autoradiograms are viewed with phase-contrast microscopy. Figure 3 clearly demonstrates that the combination of mitogens results in a higher SC labeling index when compared to rHRG $\beta 1_{177-}$ ${ }_{244}$ alone. As this was the only combination of mitogens (Rutkowski et al., 1992) that resulted in a higher labeling index for $\mathrm{SCs}$ than Fbs, these mitogens were used to expand human SCs in culture.

The influence of $\mathrm{rHRG} \beta 1_{177-244}$ alone or in combination with CT and forskolin on the expansion of cells dissociated from a number of peripheral nerve donors is summarized in Figure 4. In accordance with the DNA synthesis results presented above 

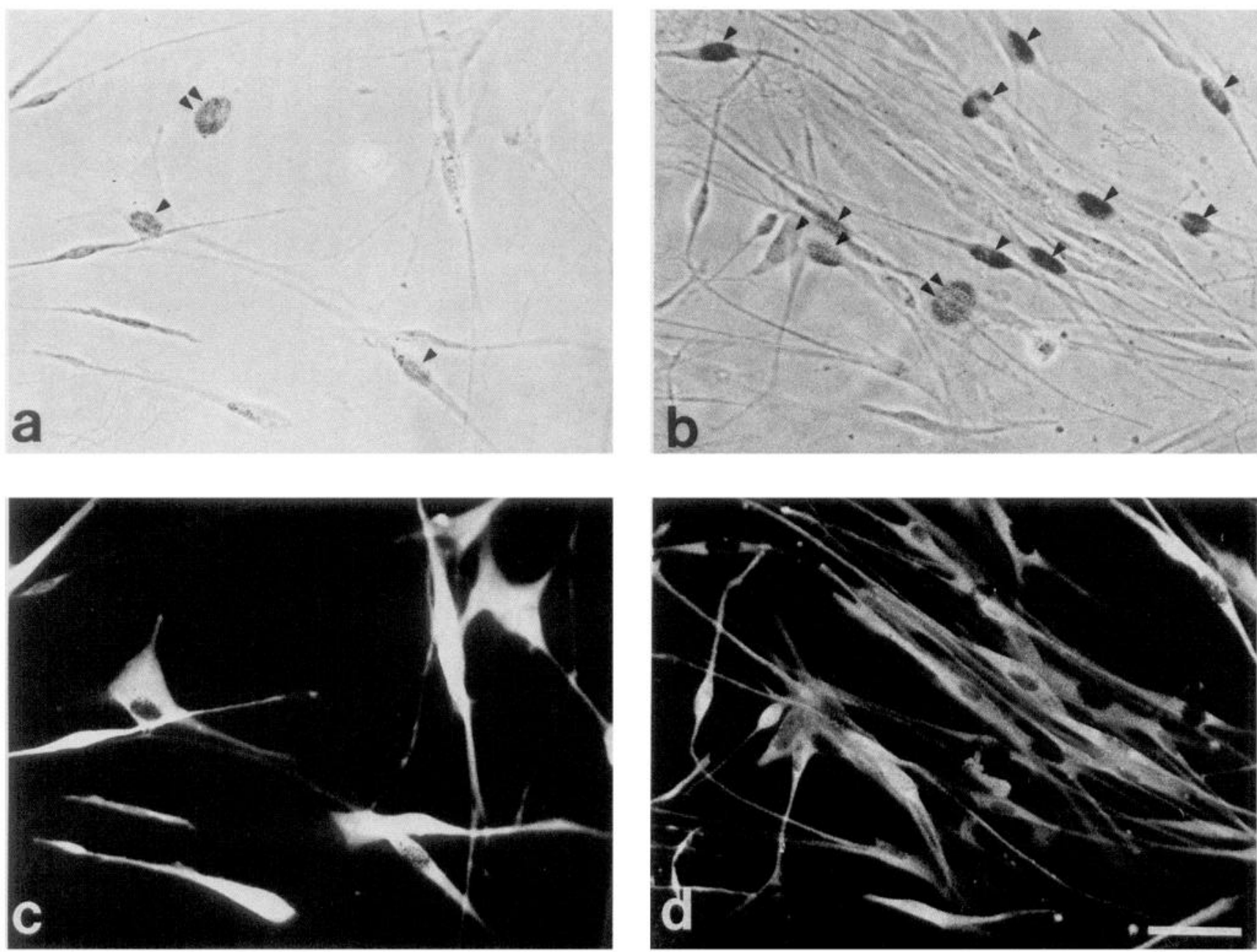

Figure 3. Phase-contrast images combined with $\mathrm{S} 100$ immunostaining of a dissociated human peripheral nerve exposed to heregulin alone ( $a$, $c$; rHRG $\left.\beta 1_{177 \cdot 244}, 10 \mathrm{~nm}\right)$ or with activators of adenyl cyclase $\left(b, d ; 10 \mathrm{~nm}\right.$ rHRG $\beta 1_{177-244}, 100 \mathrm{ng} / \mathrm{ml} \mathrm{CT}$, and $1 \mu \mathrm{M}$ forskolin). $a$ and $b$ are phase images of autoradiograms demonstrating grains over cell nuclei that have incorporated ${ }^{3} \mathrm{H}$-thymidine over the $24 \mathrm{hr}$ labeling period. $c$ and $d$ represent the same field viewed with a rhodamine filter after staining with S100 to demonstrate which of the labeled cells are Schwann cells. Single arrowheads on phase images represent SCs, while double arrowheads indicate S100 negative fibroblasts. The combination of heregulin and the activators of adenyl cyclase results in a pronounced increase in the SC labeling index. Scale bar, $50 \mu \mathrm{m}$.

(Figs. 2, 3), these data demonstrate that human SCs can be effectively expanded without overwhelming $\mathrm{Fb}$ contamination over the first four passages using a combination of the three mitogens. The addition of the aforementioned activators of adenyl cyclase is critically important in this pursuit, as rHRG $\beta 1_{177-244}$ alone results in only a modest increase in cell number and a substantial decrease in SC purity after only two passages. Concomitant to the increase in cell numbers (Fig. $4 a$ ) between P3 and P4 in cells expanded with the triple mitogens, there is also a drop in the SC purity, indicating that the actual SC numbers are not increasing relatively faster between P3 and P4. Substantial increases in human SC numbers after the fourth passage have yet to been attained.

To ascertain whether the human SCs isolated from peripheral nerve responded to the added mitogens in a relatively homogeneous manner, some cultures received long pulses of ${ }^{3} \mathrm{H}$-thymidine in the presence of the triple mitogens. In human SC preparations obtained from three different donors the average SC labeling index after 48 and $72 \mathrm{hr}$ (Fig. $5 A, B$ ) was $83.1 \% \pm$ 5.95 and $92.5 \% \pm 5.22$, respectively. The ability to induce a majority of the SCs to enter the S-phase of the cell cycle over this time period confirms that a large subpopulation of unresponsive cells is unlikely to exist in these cultures.

It has been previously determined (Levi et al., 1994a) that primary dissociated human SCs often contain abundant intracellular inclusions that represent myelin debris (Fig. 6a,c). The myelin within the human SCs prepared in culture is thought to be taken up during the process of in vitro "Wallerian degeneration" (Levi et al., 1994b). In the absence of a mitogenic stimulus (i.e., D10), the inclusions are retained within the SCs. The accumulation of myelin debris within SCs that are unable to divide has also been observed in vivo when mitomycin $\mathrm{C}$ has been injected in the proximity of a nerve injury (Hall and Gregson, 1975; Hall, 1986; Pellegrino et al., 1986). There is a rapid disappearance of SC myelin debris in culture upon exposure to the triple mitogens. This may represent an activation of myelin processing and/or dilution of the debris through serial divisions of the SC. After multiple passages, some of the human SCs accumulate intracellular inclusions (Fig. $6 b, d$ ) quite dissimilar in appearance to the aforementioned debris in that they are clear, more rounded, and larger and are only infrequently encountered. 


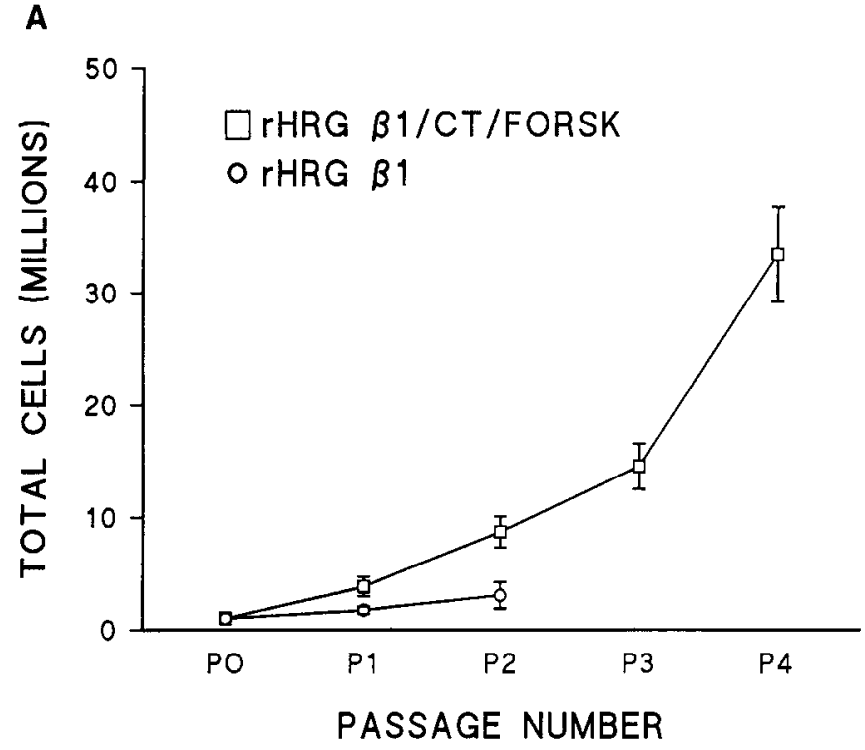

B

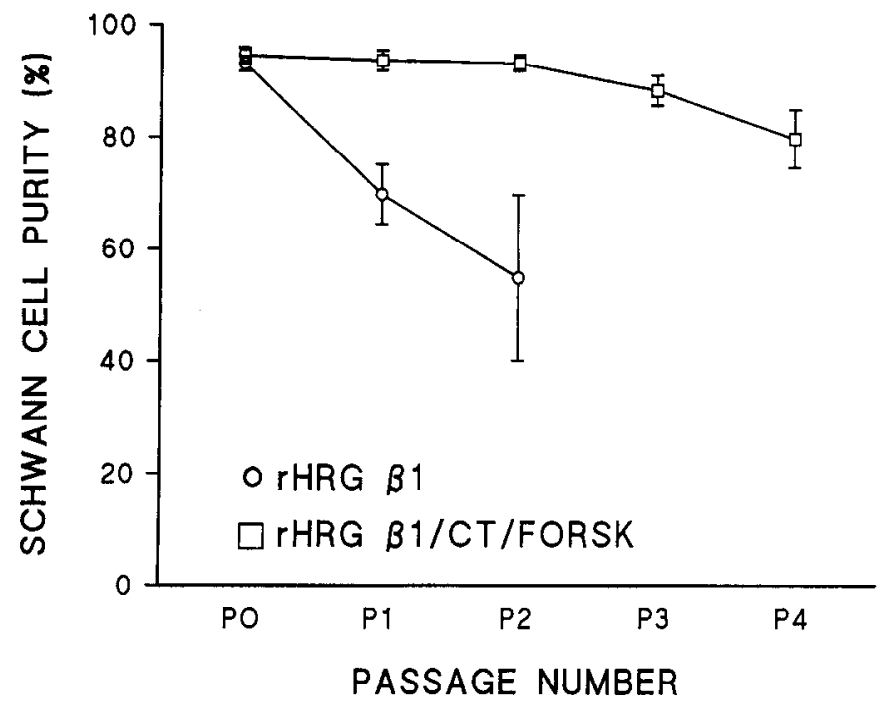

Figure 4. Cell number $(a)$ and SC purity $(b)$ over the first two passages $\left(P 0-P 2 ;\right.$ rHRG $\beta 1_{177-244}, 10 \mathrm{nM}$; three donors with an average age of 14 years) or four passages ( $10 \mathrm{~nm}$ rHRG $\beta 1_{177-244}, 100 \mathrm{ng} / \mathrm{ml} \mathrm{CT}$, and $1 \mu \mathrm{M}$ forskolin; six donors with an average age of 22 years) of cells dissociated from human peripheral nerves. There was a greater increase in total cell number with the combination of mitogens ( $\mathrm{rHRG} \beta 1_{177-244} / \mathrm{CT} /$ forskolin) when compared to rHRG $\beta 1_{177-244}$ alone. SC purity is essentially maintained over the first four passages with the combination of mitogens consistent with the results obtained with ${ }^{3} \mathrm{H}$-thymidine labeling and unequivocally establishing the ability of human SCs to proliferate under these conditions. Also consistent with the autoradiographic studies is the rapid decrease in the SC purity even after the first passage when rHRG $\beta 1_{177.244}$ alone was added. There was a loss of adhesivity of cells to the PLL substrate at P2 when rHRG $\beta 1_{177.244}$ alone was added.

\section{ErbB2, erbB3 and erbB4 are expressed in human Schwann cells}

As shown in Figure $7 A$, transcripts for erbB2, erbB3, and erbB4 could be detected by RT-PCR analysis of human SCs. The blots in Figure $7 A$ were generated using identical numbers of PCR cycles and internal oligonucleotide probes of similar specific activity. No cross-reactivity among the three receptor species was detected under these conditions; however, the erbB4 lane needed to be exposed in the image analyzer about 10 times longer than the erbB2 or erbB3 lanes. These data suggest that erbB2 and erbB3 are expressed at higher levels than erbB4 in mitogen-expanded human SCs.

Since the heregulins were originally identified as specific activators of the p $185^{\mathrm{erbB} 2}$ receptor (Holmes et al., 1992), it was of interest to determine whether erbB2 protein could be detected in human SCs. Western blot analysis using a polyclonal antibody to $\mathrm{p} 185^{\mathrm{crbB} 2}$ in our human SC cell preparations is shown in Figure $7 B$. A $185 \mathrm{kDa}$ band is clearly seen in lysates prepared from mitogen-expanded cultures (lane 2) of human SCs. For comparison a cell lysate from the breast carcinoma ccll linc MDAMB-453, which is known to express moderate levels of pl $85^{\text {erbB2 }}$ (Lewis et al., 1993), is also shown (lane 1). The specificity of the binding of this antibody to the $\mathrm{p} 185^{\mathrm{erbB} 2}$ receptor is demonstrated by the ability of the purified erbB2 extracellular domain (ECD) to attenuate the signal successfully in lysates of both the human breast cancer and Schwann cells (lanes 3, 4). These data agree with previous studies that demonstrated that p1 $85^{\text {neu }}$, the rat homolog of erbB2 is present on rat SCs (Cohen et al., 1992; Jin et al., 1993). Recently, it has been determined that HRG binds to the closely related receptor tyrosine kinase erbB3 (Carraway et al., 1994), and activation of p185 erbB2 requires coexpression of the erbB3 protein (Sliwkowski et al., 1994). Thus, it was of interest to determine if p180 ${ }^{\mathrm{erbB} 3}$ could also be detected in human SCs. Samples identical to those described above were immunostained with a polyclonal antibody directed to residues 169-336 of the ECD of the human erbB3 protein. This antibody will react with a lysate of insect cells expressing the bovine erbB3 protein as well as COS cells expressing human erbB3 but not erbB2 protein (Sliwkowski et al., 1994) but does not react with the erbB4 ECD on Western blots (L. Bald, J. Lofgren, B. M. Fendly, and M. X. Sliwkowski, unpublished observations). An immunoreactive band with a molecular size of $\sim 180-185 \mathrm{kDa}$ is detected in the MDA-MB-453 cell lysate (Fig. 7C, lane 1) as this cell line is also known to express erbB3 (Kraus et al., 1993). In agreement with RT-PCR analysis, an erbB3-immunoreactive band can also be detected in the mitogen-expanded human SCs (Fig. 7C, lane 2).

\section{p185 ${ }^{\text {erhBz }}$ is involved in heregulin signaling}

Although these data confirm that human SCs express erbB2, it was necessary to determine whether the response of human SCs to $\mathrm{rHRG} \beta 1_{177-244}$ was mediated through this receptor. In an effort to answer this question, tyrosine phosphorylation analysis was performed in the presence of monoclonal antibodies $(2 \mathrm{C} 4$, $2 \mathrm{H} 11$ ) to $\mathrm{p} 185^{\mathrm{erbB} 2}$. These well-characterized antibodies specifically recognize the extracellular domain of the human erbB2 receptor, and not the EGF receptor (Fendly et al., 1990b) or the erbB3/erbB4 receptors (L. Bald, B. M. Fendly, and M. X. Sliwkowski, unpublished observations). Some of these antibodies have antiproliferative effects in certain breast cancer lines that overexpress p1 85 ${ }^{\mathrm{erbB} 2}$ (Hudziak et al., 1989; Lewis et al., 1993). The 2C4 antibody (but not $2 \mathrm{H} 11$ ) is particularly effective in inhibiting heregulin activation of tyrosine phosphorylation and binding in cells that express erbB2 and erbB3 (Sliwkowski et al., 1994). As shown in Figure 8 , a $185 \mathrm{kDa}$ band is tyrosine phosphorylated in mitogen-expanded cultures (lane 2) after an 8 min incubation with rHRG $\beta 1_{177-244}$. The high basal level of protein tyrosine phosphorylation was likely due to the fact that these cells were not serum starved prior to the initiation of the 

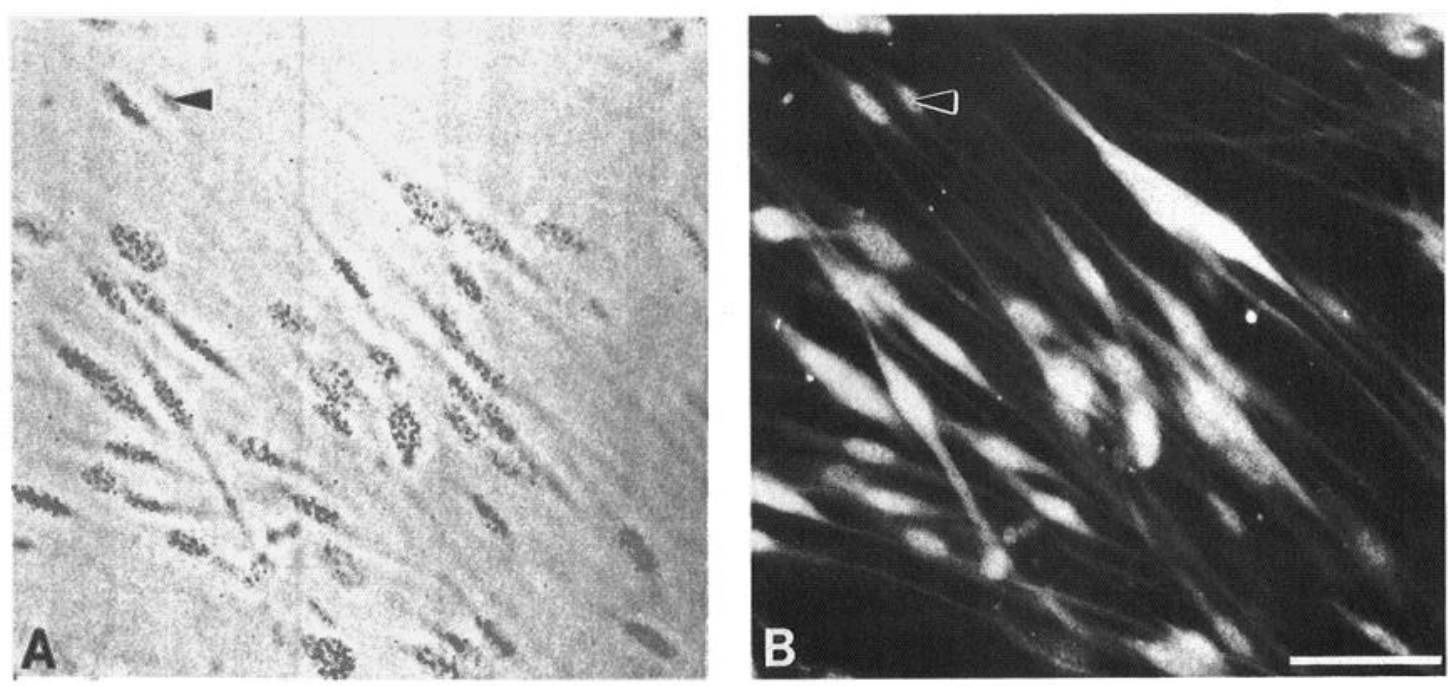

Figure 5. Phase-contrast image $(A)$ and $\mathrm{S} 100$ immunostaining $(B)$ of cells isolated from a human peripheral nerve that were exposed to rHRG $\beta 1_{177.244}(10 \mathrm{nM}), C T(100 \mathrm{ng} / \mathrm{ml})$, and forskolin $(1 \mu \mathrm{M})$. The phase image of the autoradiogram demonstrates that a majority of the human SCs $\left(\mathrm{S} 00^{+}\right)$contain grains over their cell nuclei after a $72 \mathrm{hr}$ labeling period with ${ }^{3} \mathrm{H}$-thymidine. There is one S100-positive cell in this field that is negative (arrowhead). Scale bar, $50 \mu \mathrm{m}$.

phosphorylation assays. In these cells the phosphorylation signal was significantly diminished when SCs were preincubated with the blocking anti-p $185^{\mathrm{erbB} 2}$ antibody $2 \mathrm{C} 4$ (lane 4). Tyrosine phosphorylation was not inhibited when SCs were preincubated with a control anti-p185 erbB2 antibody, 2H11 (lane 3). Previous studies have shown that the $\mathrm{EC}_{50}$ for the rHRG $\beta 1_{177-244}$-stimulated tyrosine phosphorylation of a $185 \mathrm{kDa}$ in the breast carcinoma cell line MCF-7 was $\sim 0.05 \mathrm{~nm}$ (Holmes et al., 1992) and a maximal phosphorylation signal is obtained using $0.3 \mathrm{~nm}$ rHRG $\beta 1_{177.244}$. A similar response appears to be occurring with the $\mathrm{SCs}$, in that cells treated with $1 \mathrm{nM}$ rHRG $\beta 1_{177-244}$ (lane 2) or the control antibody (lane 3), $2 \mathrm{H} 11$, followed by $0.3 \mathrm{nM}$ rHRG $\beta 1_{177.244}$ generate a tyrosine phosphorylation signal of nearly equal intensity. SC cultures derived from adult human peripheral nerve contain some Fbs, so it is important that it has been previously demonstrated that rat SCs but not Fbs specifically immunostain with anti-p185 1 neu (Jin et al., 1993). In addition, exposure of Fbs to ARIA and NDF in various cell culture systems (Corfas et al., 1993; Peles et al., 1993) does not result in the phosphorylation of the putative $185 \mathrm{kDa}$ receptor.

To determine if the effects of rHRG $\beta 1_{177.244}$ on human SC division are also mediated by the p185 ${ }^{\mathrm{erbB} 2}$ receptor, labeling indices were determined for SCs and Fbs in the presence and absence of the 2C4 antibody (Fig. 9). As with the tyrosine phosphorylation assays, the $2 \mathrm{C} 4$ antibody, but not the control antibody $(2 \mathrm{H} 11)$, significantly $(p<0.01)$ attenuated the rHRG $\beta 1_{177.244}$-induced ${ }^{3} \mathrm{H}$-thymidine labeling of human SCs, but had no effect on the already high $\mathrm{Fb}$ labeling index. These results strongly suggest that the rHRG $\beta 1_{177.244}$ effect on human SC proliferation is at least partially mediated by the p $185^{\mathrm{erbB} 2}$ receptor, and further supports the view that human $\mathrm{Fb}$ proliferation in this culture system does not involve this receptor.

\section{Discussion}

The heregulins were initially purified from media conditioned by a human breast tumor cell line based on their ability to phosphorylate p185 ${ }^{\text {erbB2 }}$ (Holmes et al., 1992). While this family of proteins ( $\alpha$ and $\beta \mathrm{s}$ ) are able to stimulate the growth of certain breast cancer cell lines that overexpress the p185 ${ }^{\mathrm{erbB} 2}$ receptor
(Holmes et al., 1992), their role in normal cell growth and differentiation is less clear. Several full-length cDNA clones that encode GGF proteins with SC mitogenic activity have been constructed from a human genomic library (Marchionni et al., 1993). These GGF cDNA clones represent alternatively spliced mRNAs from a single gene. This gene also encodes the HRGs, NDF, and ARIA (Falls et al., 1993; Marchionni et al., 1993). Certain of the deduced amino acid sequences from the human GGF and heregulin cDNAs are identical (GGFHFB1 and HRG $\beta 3$; Holmes et al., 1992; Marchionni et al., 1993), while others represent novel structures. NDF and ARIA gene products have been characterized in the rat and chicken, respectively (Wen et al., 1992; Falls et al., 1993), and differences in the deduced amino acid sequence of these proteins with heregulin represent a combination of evolutionary divergence as well as alternative splicing (Falls et al., 1993). The activities of GGF (Lemke and Brockes, 1984) and ARIA (Usdin and Fischbach, 1986) have been defined in the context of SC and muscle biology, respectively. Given the recently discovered relationship between HRG, NDF, GGF, and ARIA, it is important to define whether the activities of individual members of this family of related proteins are overlapping.

Recombinant HRG proteins (Holmes et al., 1992) are ideal candidates to test as potential mitogens for human SCs: they are products of human genes, some of the HRG proteins are identical to deduced human GGF protein sequences, they appear to activate the same receptor family (Cohen et al., 1992; Holmes et al., 1992; Marchionni et al., 1993), and the receptor binding regions of the full-length protein have been characterized and can be uniquely expressed. While recombinant fulllength $\mathrm{HRG} \beta 1$ is synthesized in mammalian cells, the truncated version ( $r$ RRG $\beta 1_{177-244}$ ) is expressed in Escherichia coli and only comprises the nonglycosylated EGF-like structural unit and immediate flanking regions (Holmes et al., 1992).

rHRG $\beta 1_{177-244}$ is a potent mitogen for human SC as measured by its ability to induce SCs to enter the S phase of the cell cycle. However, the addition of HRG alone results in an SC labeling index that is well below the $\mathrm{Fb}$ labeling index in serum-containing media. In an effort to define conditions that would permit 

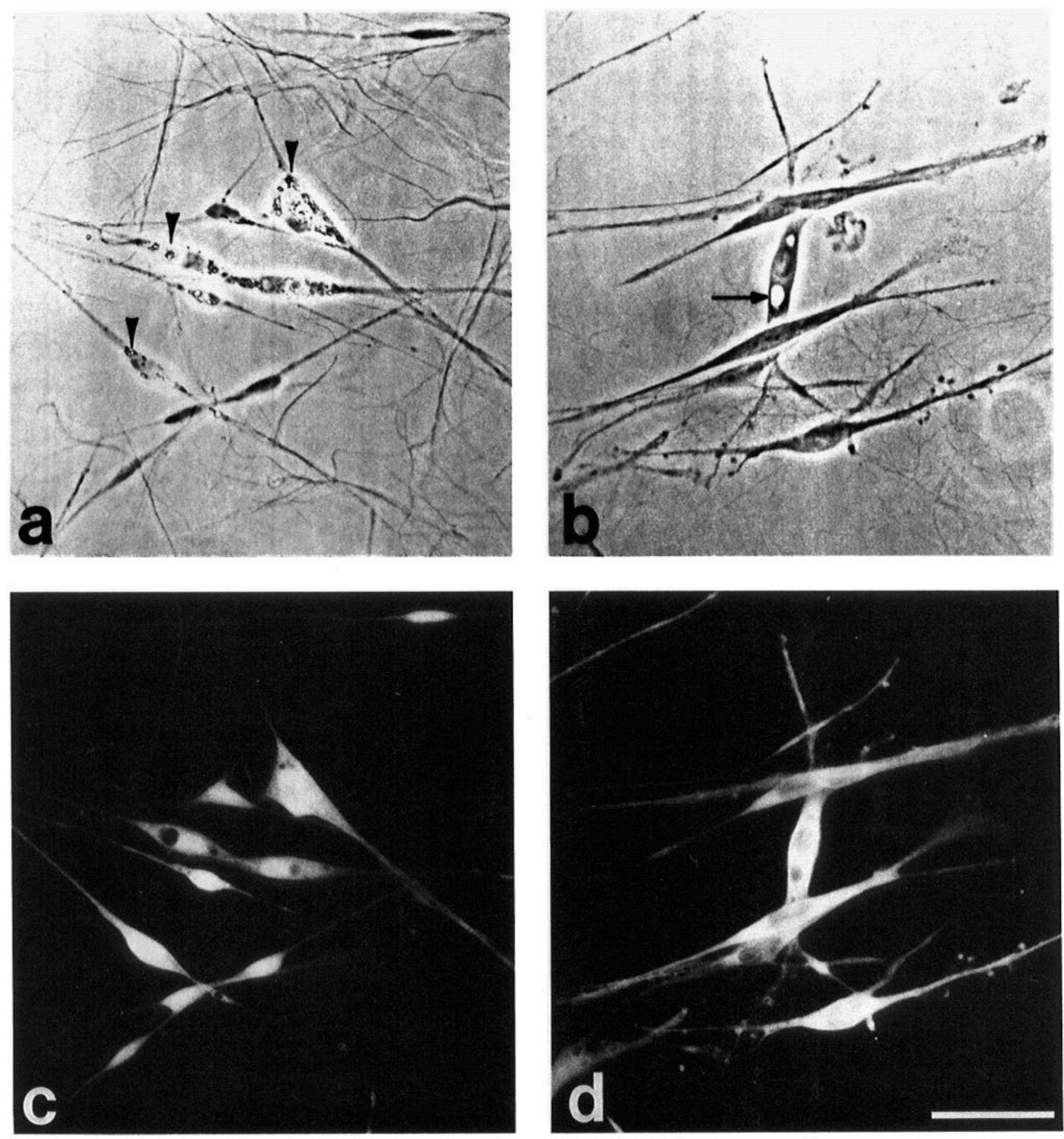

Figure 6. Photomicrographs of primary and expanded human SCs: primary dissociated cells $(a, c)$ from human peripheral nerve explants (P0) seen in phase $(a)$ or after immunostaining with S100 $(c)$. Many of the SCs contain abundant phase refractile myelin debris $(a r r o w h e a d s)$. Expanded (P3) human SCs $(b, d)$ have a flattened appearance with no myelin debris. One SC has accumulated clear intracellular vesicles $(b)$ during the expansion (arrow). $d$ is the same field as $b$ viewed with $\mathrm{S} 100$ immunostaining. Scale bar, $50 \mu \mathrm{m}$.

expansion of human SCs, activators of adenyl cyclase were added. CT and forskolin have been shown to act in synergy with polypeptide growth factors (GGF, TGF $\beta 1$, PDGF, FGF) in promoting SC division (Raff et al., 1978a; Porter et al., 1986; Ridley et al., 1989; Davis and Stroobant, 1990; Rutkowski et al., 1992). While these agents were initially considered to be potent SC mitogens in themselves (Raff et al., 1978a,b), recent evidence suggests (Davis and Stroobant, 1990; for a review, see Lemke, 1990) that they may simply modulate the response to polypeptide growth factors already present in serum (PDGF,
TGF $\beta 1, F G F)$. In the case of PDGF, the addition of forskolin upregulates this mitogen's receptor within SCs (Weinmaster and Lemke, 1990).

The addition of CT or forskolin alone was relatively ineffective in inducing human SCs to enter the $\mathrm{S}$ phase of the cell cycle. This is in marked contrast to the high labeling index seen in rat SCs exposed to CT (Raff et al., 1978a), and is consistent with the relative insensitivity of human SCs to mitogens that are effective for rat SCs. The addition of CT or forskolin to rHRG $\beta 1_{177-244}(10 \mathrm{nM})$ resulted in a marked synergy, such that the 


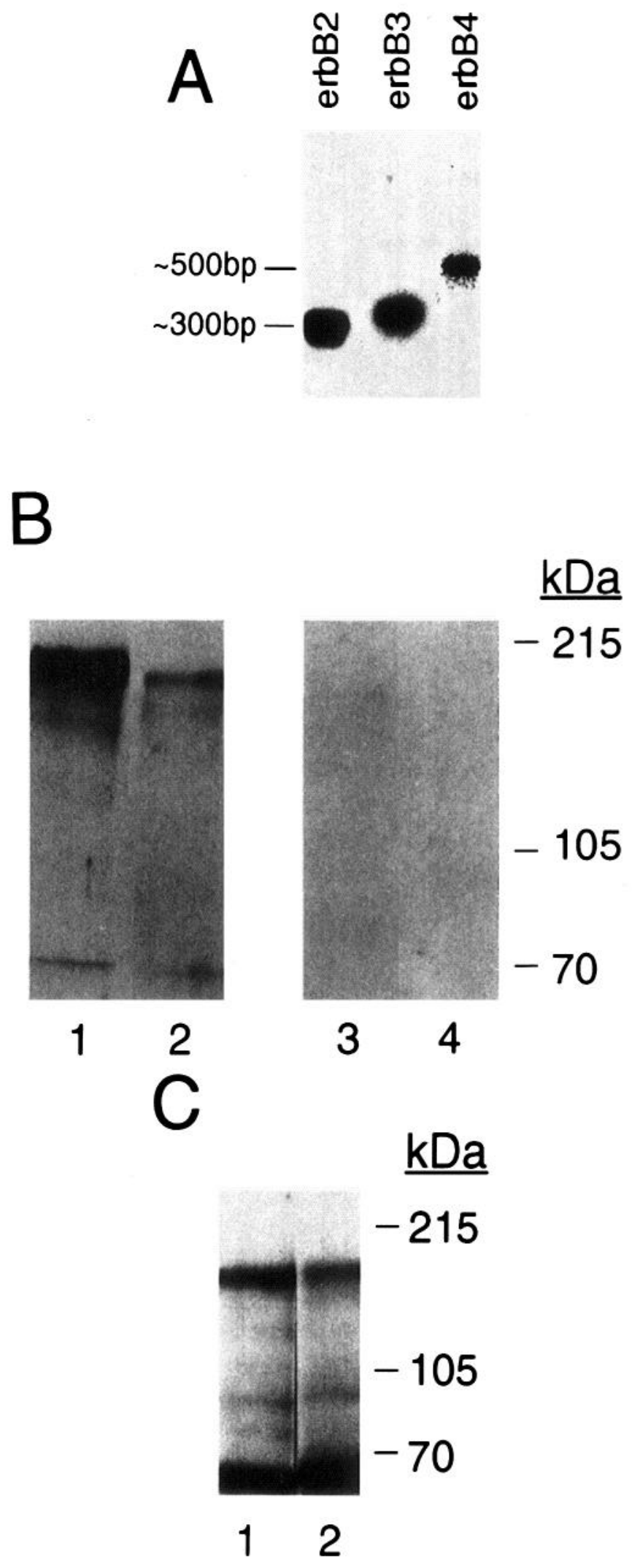

Figure 7. A, RT-PCR analysis of erbB2, erbB3, and erbB4 expression in expanded human SCs. The products of the specific RT-PCR reactions for the three receptors were separated by gel electrophoresis, blotted, and then probed with labeled oligonucleotides. They were then exposed with a Fuji BAS BioImage Analyzer as described in Material and Methods. This panel represents the output from the image analyzer. $B$, Western blot analysis for erbB2 expression. Lane 1, cell lysate of MDA-MB-

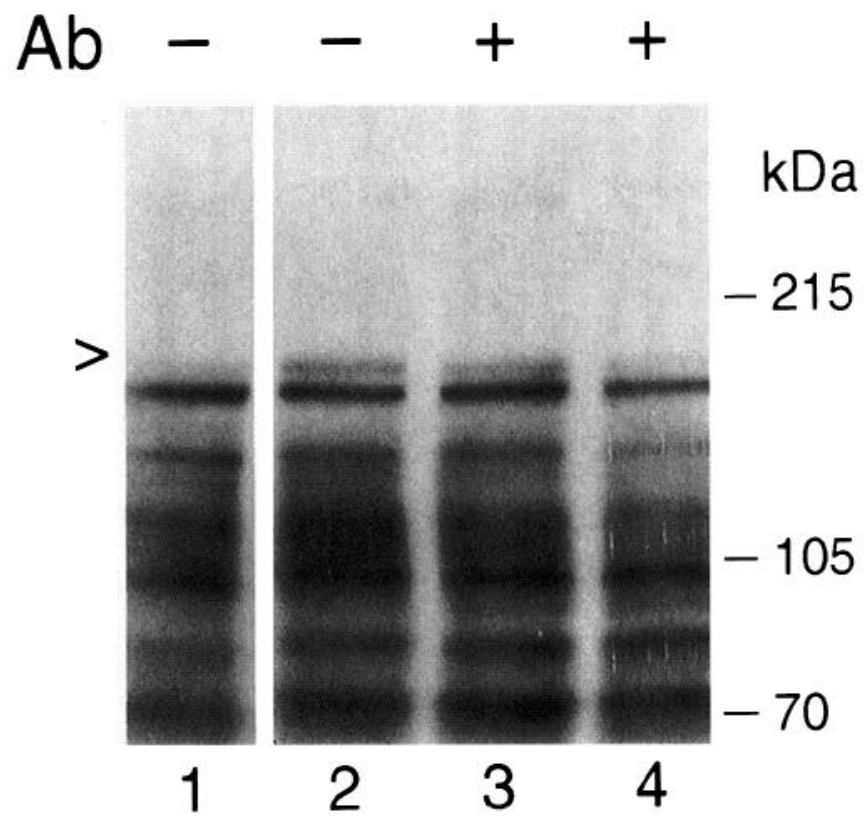

Figure 8. Heregulin-stimulated tyrosine phosphorylation of human SC proteins in the absence or presence of anti-p185 erbB2 monoclonal antibodies. Expanded human SCs (lanes 1-4) were preincubated for $30 \mathrm{~min}$ in control buffer (-) or antibody ( $+; 2 \mathrm{H} 11$ or $2 \mathrm{C} 4,100 \mathrm{~nm})$. Various concentrations of rHRG $\beta 1_{177-244}$ were then added and incubations were continued for an additional $8 \mathrm{~min}$. The blots were then probed with anti-phosphotyrosine antibodies. Lane 1, control buffer; lane 2, $1 \mathrm{~nm}$ rHRG $\beta 1_{177-244}$; lane 3 , preincubation with the control monoclonal antibody $2 \mathrm{H} 11$ and then with $0.3 \mathrm{~nm}$ rHRG $\beta 1_{177.244}$; lane 4 , preincubation with the heregulin-blocking monoclonal antibody $2 \mathrm{C} 4$ and then with $0.3 \mathrm{~nm}$ rHRG $\beta 1_{177-244}$. Addition of rHRG $\beta 1_{177-244}$ alone (1 nM; lane 2) results in phosphorylation of a protein with $M_{r}$ of $185 \mathrm{kDa}$. Compare upper band at $185 \mathrm{kDa}$ in lane 2 (rHRG $\beta 1_{177-244}, 1 \mathrm{~nm}$ )) with lane 1 (control sample buffer). Preincubation of cells with the anti-p185 erbB2 antibody $(2 \mathrm{C} 4$, but not $2 \mathrm{HIl})$ results in inhibition of phosphorylation of this $185 \mathrm{kDa}$ protein in response to added rHRG $\beta 1_{177-244}(0.3 \mathrm{~nm})$. Experiments were repeated at least three times.

human SC labeling index essentially doubled when compared to rHRG $\beta 1_{177-244}$ alone. A similar effect was observed with pituitary extract or crude GGF preparations on dissociated rat SCs whether CT (Raff et al., 1978a) or forskolin (Porter et al., 1986) was used as the agent to elevate cAMP. In that GGF and rHRG $\beta 1_{177-244}$ are likely operating through homologous receptors (Holmes et al., 1992; Marchionni et al., 1993), whether in the human ( $\left.185^{\mathrm{erbB} 2}\right)$ or the rat (p185 $\left.5^{\text {neu }}\right)$, the synergy of $\mathrm{rHRG}$ $\beta 1_{177-244}$ and the activators of adenyl cyclase is consistent with the finding that addition of forskolin to GGF is capable of upregulating the expression of $185^{\text {neu }}$ message (Cohen et al., 1992 ) and a $185 \mathrm{kDa}$ phosphorylated protein (Marchionni et al., 1993) in cultured rat SCs.

453 cells; lane 2, cell lysate of expanded human SCs. Blots were probed with an affinity-purified rabbit antibody directed against the extracellular domain (ECD) of p185 erbB2. Lanes 3 and 4 are identical to lanes 1 and 2 except antibody was preincubated with $60 \mu \mathrm{g}$ of purified erbB2 ECD. Immunoreactive bands were visualized after incubation with horseradish peroxidase-conjugated secondary antibody. $C$, Western blot analysis for erbB3 expression. Lane 1, cell lysate of MDA-MB-453 cells; lane 2, cell lysate of mitogen-expanded human Schwann cells. Blots were probed with an affinity-purified rabbit antibody directed against residues $169-366$ of the ECD of p180 $80^{\text {rbB } 3}$. Immunoreactive bands were visualized as described above. 


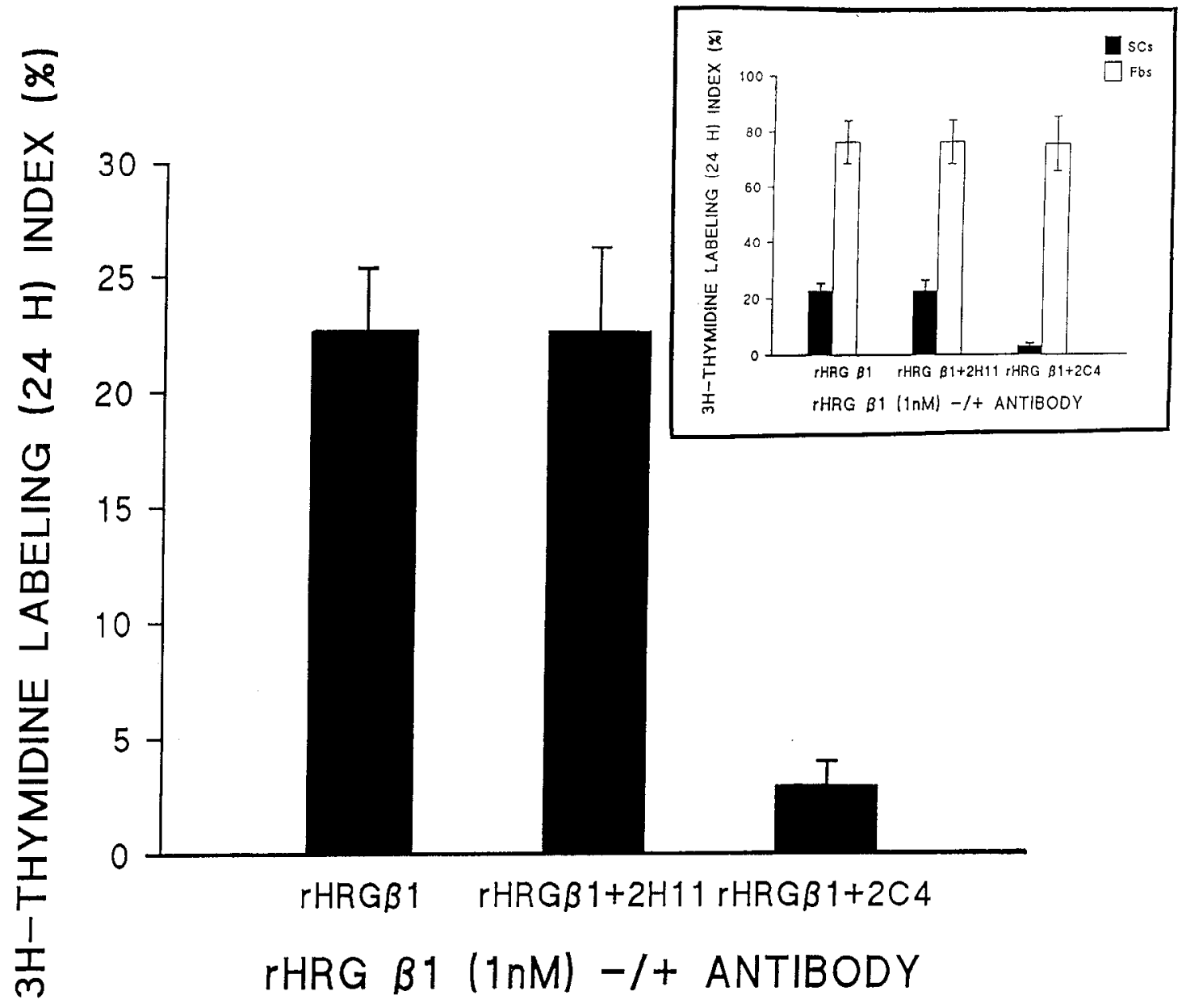

Figure 9. Labeling indices ( $24 \mathrm{hr}$ ) of human SCs and Fbs (inset) in media containing D10 and rHRG $\beta 1_{177-244}(1 \mathrm{nM})$ in the absence or presence of monoclonal antibodies $(2 \mathrm{H} 11 / 2 \mathrm{C} 4,100 \mathrm{~nm})$ to the p185 erbB2 receptor. While both antibodies have been shown to bind to the receptor, only preincubation with the $2 \mathrm{C} 4$ antibody effectively blocks the rHRG $\beta 1_{177-244}$-induced labeling of human $\mathrm{SCs}(p<0.01)$. The experiment was repeated with four different donors $(n=4)$ whose average age was 24 years.

The addition of both activators of adenyl cyclase (forskolin and cholera toxin) to rHRG $\beta 1_{177-244}$ did not enhance the SC labeling index, but appeared to depress the $\mathrm{Fb}$ labeling index significantly when compared to rHRG $\beta 1_{177-244}$ alone. In contrast to the SC, a rise in cAMP levels within human Fbs tends to inhibit cell division (Froehlich and Rachmeler, 1972; Hollenberg and Cuatrecasas, 1973; Heldin et al., 1989; Rutkowski et al., 1992), and may play a physiological role in signaling Fbs to cease growth at confluency in cell culture (Pastan et al., 1975). The inhibition of human $\mathrm{Fb}$ labeling seen when the two activators of adenyl cyclase are added to rHRG $\beta 1_{177-244}$ may result from the ability of forskolin to potentiate the CT induction of cAMP levels within cells (Barovsky and Brooker, 1985). It is fortuitous that agents that elevate cAMP level within the two main cell types of dissociated human peripheral nerve explants, Schwann cells and fibroblasts, have opposite effects on cell division.

The ability to induce a majority ( $\sim 90 \%)$ of the SCs to enter the S phase of the cell cycle after long pulses ( 48 and $72 \mathrm{hr}$ ) of ${ }^{3} \mathrm{H}$-thymidine suggests that the human SCs, at least initially, are relatively homogeneous in their response to the added mitogens. While a subpopulation of rapidly dividing cells could potentially be counted twice during a $24 \mathrm{hr}$ labeling index, most mammalian cells have a cell cycle of 18-24 hr (Alberts et al., 1989). Prelim- inary observations suggest that the cell cycle time in human SCs that have been exposed to the triple mitogens is comparable.

The erbB2 protooncogene encodes a receptor tyrosine kinase, p185 ${ }^{\text {erb32 }}$, with extensive homology to the human EGF receptor (Coussens et al., 1985). Amplification and/or overexpression of erbB2 has been detected in a variety of human malignancies and is found frequently in human mammary carcinomas (Slamon et al., 1987) and breast tumor-derived cell lines (Lewis et al., 1993). rHRG $\beta 1_{177-244}$ has been shown to bind to human breast cancer cells and increase tyrosine phosphorylation p $185^{\mathrm{erbB} 2}$ in these cells (Holmes et al., 1992). The putative GGF receptor on rat SCs is also a $185 \mathrm{kDa}$ protein that is phosphorylated on tyrosine residues when exposed to GGF (Marchionni et al., 1993). Using specific oligonucleotide probes and antibodies, we demonstrate that both the erbB2/erbB3 messages as well as proteins are present in cultured human SCs. While antibody reagents for $\mathrm{p} 180^{\mathrm{erbB} B / H E R-4}$ were not available for this study, we could detect message for this receptor within the human SCs. Our assays also indicated that the addition of rHRG $\beta 1_{177-244}$ to the cells results in the phosphorylation of a $185 \mathrm{kDa}$ protein on a tyrosine residue.

The importance of $\mathrm{p} 185^{\mathrm{erb} B 2}$ in transducing the heregulin signal in human SCs was confirmed using a specific blocking monoclonal antibody (2C4) to this receptor. Our results demonstrate 
that the $2 \mathrm{C} 4$ antibody inhibits tyrosine phosphorylation of a $185 \mathrm{kDa}$ protein in human SCs and the incorporation of ${ }^{3} \mathrm{H}$ thymidine within human SCs when these cells are exposed to $\mathrm{rHRG} \beta 1_{177-244}$. These data provide strong evidence that $\mathrm{p} 185^{\mathrm{crbB} 2}$ is important in mediating the mitogenic effects of heregulin on human SCs.

It is known that $\mathrm{HRG} / \mathrm{NDF}$ activation of $\mathrm{p} 185^{\mathrm{crbB} 2}$ does not occur in all cells that express erbB2. It has been postulated that another component might be required for $\mathrm{HRG} / \mathrm{NDF}$ activation of p185 erbB2 (Peles et al., 1993). Two possible candidates that might mediate this responsiveness are the closely related receptor tyrosine kinases erbB3/HER-3 (Kraus et al., 1989; Plowman et al., 1990) and the newly discovered erbB4/HER-4 (Plowman et al., 1993a). We have demonstrated here that a protein that is immunologically related to erbB3 and the erbB3 message can be readily detected in mitogen-stimulated human SCs. In a related study we have determined that $\operatorname{HRG} \beta 1_{177-244}$ will bind to the erbB3 protein (Carraway et al., 1994) and that, in the presence of erbB3, erbB2 is capable of binding HRG. Reconstitution of a high-affinity heregulin signaling receptor can be achieved by coexpression of erbB3 with erbB2 (Sliwkowski et al., 1994).

Recently, it has also been reported that a heregulin-like protein will bind and activate p180 1 erbB4/HER-4 (Plowman et al., 1993b). Our experiments indicate that the message to erbB4/HER-4 can be detected in human SCs. Although erbB4 may be a receptor involved in heregulin signaling in human SCs, the ability to attenuate the mitogenic signal of heregulin by a blocking monoclonal antibody (2C4) that specifically recognizes erbB2 and not erbB3/4 suggests an important role for the erbB2 receptor in signal transduction. It remains to be determined whether erbB2 may mediate this signal through the formation of heterodimers with either erbB3 or erbB4 or potentially another member of this family of receptors.

This study has established that $\mathrm{rHRG} \beta 1_{177-244}$, a truncated member of the heregulin family, is a potent mitogen for human SCs isolated from peripheral nerve. It is particularly effective when combined with agents that elevate cAMP levels. In carefully counting cell numbers and determining SC purity when the mitogens are added, we have unequivocally established that the human SC can be induced to divide in culture and their numbers can be substantially increased. The ability to expand human SCs in culture combined with the recent demonstration of the functional expression of human SCs prepared in culture when transplanted into immune deficient rodents (Levi et al., 1994a) clcarly advances the possibility of pursuing an autotransplantation paradigm in the repair of human central and peripheral nerve injuries. Several questions need to be addressed before such an autotransplantation paradigm could be used clinically; What is the fate of cultured human Schwann cells after longterm exposure to these potent mitogens (Sager, 1989; Goldstein, 1990)? Will human SCs expanded in culture retain their ability to promote regeneration and myelinate regenerating axons (Feltri et al., 1992)? Finally, will these human Schwann cells retain normal growth characteristics (and not form tumors when transplanted) after extensive expansion on mitogens (Langford et al., 1988)?

\section{References}

Acheson A, Barker PA, Alderson RF, Miller FD, Murphy RA (1991) Detection of brain-derived neurotrophic factor-like activity in fibroblasts and Schwann cells: inhibition by antibodics to NGF. Ncuron $7: 265-275$.
Alberts B, Bray D, Lewis J, Raff M, Roberts K, Watson JD (1989) Molecular biology of the cell, 2d ed. New York: Garland.

Asbury AK (1967) Schwann cell proliferation in developing mouse sciatic nerve. J Cell Biol 34:735-743.

Barovsky K, Brooker G (1985) Forskolin potentiation of cholera toxin stimulated cyclic AMP accumulation in intact C6-2B cells. Evidence for enhanced Gs-C coupling. Mol Pharmacol 28:502-507.

Bixby JL, Lilien J, Reichardt LF (1988) Identification of the major proteins that promote neuronal process outgrowth on Schwann cells in vitro. J Cell Biol 107:353-361.

Bunge RP, Bunge MB (1983) Interrelationship between Schwann cell function and extracellular matrix production. Trends Neurosci 6:499505.

Carraway KL III, Sliwkowski MX, Akita RW, Platko JL, Guy PM, Nuijens A, Diamonti AJ, Cantley LC, Cerione RA (1994) The erbB3 gene product is a receptor for heregulin. J Biol Chem 269:1430314306.

Cohen JA, Yachnis AT, Arai M, Davis JG, Scherer SS (1992) Expression of the neu proto-oncogene by Schwann cells during peripheral development and Wallerian degeneration. J Neurosci Res 31:622634.

Corfas G, Falls DL, Fischbach GD (1993) ARIA, a protein that stimulates acetylcholine receptor synthesis, also induces tyrosine phosphorylation of a $185-\mathrm{kDa}$ muscle transmembrane protein. Proc Natl Acad Sci USA 90:1624-1628.

Coussens L, Yang-Feng TL, Liao Y-C, Chen E, Gray A, McGrath J, Sccburg PH, Libcrmann TW, Schlcssinger J, Francke U, Lcvinson A, Ullrich A (1985) Tyrosine kinase receptor with extensive homology to EGF receptor shares chromosomal location with neu oncogene. Science 230:1132-1139.

Daniloff JK, Levi G, Grumet M, Rieger F, Edelman GM (1986) Altered expression of neuronal cell adhesion molecules induced by nerve injury and repair. J Cell Biol 103:929-945.

David S, Aguayo AJ (1981) Axonal elongation in peripheral nervous system "bridges" after central nervous system injury in adult rat. Science 214:391-393.

Davis JB, Stroobant P (1990) Platelet-derived growth factors and fibroblast growth factors are mitogens for rat Schwann cells. J Cell Biol 110:1353-1360.

De Vries GH (1993) Schwann cell proliferation. In: Peripheral neuropathy, 3d ed (Dyck PJ, Thomas PK, Griffin JW, Low PA, Poduslo JF, eds), pp 290-298. Philadelphia: Saunders.

Falls DL, Rosen KM, Corfas G, Lane WS, Fischbach GD (1993) ARIA, a protein that stimulates acetylcholine receptor synthesis, is a member of the neu ligand family. Cell 72:801-815.

Feltri LM, Scherer SS, Wrabetz L, Kamholz J, Shy ME (1992) Mitogen-expanded Schwann cells retain the capacity to myelinate regenerating axons after transplantation into rat sciatic nerve. Proc Natl Acad Sci USA 89:8827-8831.

Fendly BM, Kotts C, Vetterlein D, Lewis GD, Winget M, Carver ME, Watson SR, Sarup J, Saks S, Ullrich A, Shepard M (1990a) The extracellular domain of HER-2/neu is a potential immunogen for active specific immunotherapy of breast cancer. J Biol Resp Mod 9:449-455.

Fendly BM, Winget M, Hudziak RM, Lipari MT, Napier MA, Ullrich A (1990b) Characterization of murine monoclonal antibodies reactive to either the human epidermal growth factor or HER2/neu gene product. Cancer Res 50:1550-1558.

Friedman B, Scherer SS, Rudge JS, Helgren M, Morrisey D, McClain J, Wang D-Y, Wiegrand SJ, Furth ME, Lindsay RM, Ip NY (1992) Regulation of ciliary neurotrophic expression in myelin related Schwann cells in vivo. Neuron 9:295-305.

Froehlich JF, Rachmeler M (1972) Effect of 3'-5'-cyclic monophosphate on cell proliferation. J Cell Biol 55:19-31.

Gallico GG, O'Connor NE, Compton CC, Kehinde O, Green H (1984) Permanent coverage of large burn wounds with autologous cultured human epithelium. N Engl J Med 311:448-451.

Goldstein S (1990) Replicative senescence: the human fibroblast comes of age. Science 249:1 129-1132.

Goodearl ADJ, Davis JB, Mistry K, Minghetti L, Otsu M, Waterfield MD, Stroobant P (1993) Purification of multiple forms of glial growth factor. J Biol Chem 268:18095-18102.

Green H, Kehinde O, Thomas J (1979) Growth of cultured human epidermal cells into multiple epithelia suitable for grafting. Proc Natl Acad Sci USA 76:5665-5668. 
Guénard V, Kleitman N, Morrissey TK, Bunge RP, Aebischer P (1992) Syngeneic Schwann cells derived from adult nerves seeded in semipermeable guidance channels enhance peripheral nerve regeneration. J Neurosci 12:3310-3320.

Guénard V, Xu XM, Bunge M (1993) The use of Schwann cell transplantation to foster central nervous system repair. Semin Neurosci 5:401-411.

Hall SM (1986) The effect of inhibiting Schwann cell mitosis on the reinnervation of acellular autografts in the peripheral nervous system. Neuropathol Appl Neurobiol 12:401-414

Hall SM, Gregson NA (1975) The effect of mitomycin C on the process of remyelination in the mammalian peripheral nervous system. Neuropathol Appl Neurobiol 1:149-170.

Heldin N-E, Paulsson Y, Forsberg K, Heldin C-H, Westermark B (1989) Induction of cAMP synthesis by forskolin is followed by a reduction in the expression of c-myc messenger RNA and inhibition of ${ }^{3} \mathrm{H}$ thymidine incorporation in human fibroblasts. J Cell Physiol 138:1723.

Heumann R, Korsching S, Bandtlow C, Thoenen H (1987) Changes of NGF synthesis in non-neuronal cells in response to sciatic nerve transection. J Cell Biol 104:1623-1631.

Hollenberg MD, Cuatrecasas P (1973) Epidermal growth factor: receptors in human fibroblasts and modulation of action by cholera toxin. Proc Natl Acad Sci USA 70:2964-2968.

Holmes WE, Sliwkowski MX, Akita RW, Henzel WJ, Lee J, Park JW, Yansura D, Abadi N, Raab H, Lewis GD, Shepard M, Kuang WJ, Wood WI, Goeddel DV, Vandlen RL (1992) Identification of heregulin, a specific activator of p185 erbB2. Science 256:1205-1210.

Hudziak RM, Lewis GD, Winget M, Fendly BM, Shepard M, Ulrich A (1989) p185 ${ }^{\text {HER2 }}$ monoclonal antibody has antiproliferative effects in vitro and sensitizes human breast tumor cells to tumor necrosis factor. Mol Cell Biol 9:1165-1172.

Jin J-J, Nikitin AY, Rajewsky MF (1993) Schwann cell lineage-specific neu (erbB-2) gene expression in the developing rat nervous system. Cell Growth Differ 4:227-237.

Kraus MH, Issing W, Miki T, Popescu NC, Aaronson SA (1989) Isolation and characterization of ERBB3, a third member of the ERBB epidermal growth factor receptor family: evidence for overexpression in a subset of human mammary tumors. Proc Natl Acad Sci USA 86:9193-9197.

Kraus MH, Fedi P, Starks V, Muraro R, Aaronson SA (1993) Demonstration of a ligand dependent signaling by the erbB3-tyrosine kinase and its constitutive activation in human breast tumor cells. Proc Natl Acad Sci USA 90:2900-2904.

Langford LA, Porter S, Bunge RP (1988) Immortalized rat Schwann cells produce tumors in vivo. J Neurocytol 17:521-529.

Lemke GE (1990) Glial growth factors. Semin Neurosci 2:437-443.

Lemke GE (1993) Recitative and aria. Nature 362:291-292.

Lemke GE, Brockes JP (1984) Identification and purification of glial growth factor. J Neurosci 4:75-83.

Levi ADO, Guénard V, Aebischer P, Bunge RP (1994a) The functional characteristics of Schwann cells cultured from human peripheral nerve after transplantation into a gap within the rat sciatic nerve. J Neurosci 14:1309-1319.

Levi ADO, Evans PJ, Mackinnon SE, Bunge RP (1994b) Cold storage of peripheral nerves: an in vitro assay of cell viability and function. Glia 10:121-131.

Lewis GD, Figari I, Fendly BM, Wong WL, Carter P, Gorman C, Shepard HM (1993) Differential response of human tumor cell lines to anti-p $185^{\mathrm{HER} 2}$ monoclonal antibodies. Cancer Immunol Immunother 37:255-263.

Marchionni MA, Goodearl ADJ, Chen MS, Bermingham-McDonogh O, Kirk C, Hendricks M, Danehy F, Misumi D, Sudhalter J, Kobayashi $\mathrm{K}$, Wroblewski D, Lynch C, Baldasare M, Hiles I, Davis JB, Hsuan JJ, Totty NF, Otsu M, McBurney RN, Waterfield MD, Stroobant P, Gwynne D (1993) Glial growth factors are alternatively spliced erbB2 ligands expressed in the nervous system. Nature 362 : 312-318.

Morgan L, Jessen KR, Mirsky R (1991) The cffects of cAMP on differentiation of cultured Schwann cells: progression from an early phenotype $\left(\mathrm{O}^{+}\right)$to a myelin phenotype $\left(\mathrm{P}_{\mathrm{o}}^{+}, \mathrm{GFAP}-\mathrm{N}^{-} \mathrm{CAM}^{-}\right.$, NGF-receptor ${ }^{-}$) depends on growth inhibition. J Cell Biol 112:457467.

Morrissey TK, Kleitman N, Bunge RP (1991a) Isolation and func- tional characterization of Schwann cells derived from adult peripheral nerve. J Neurosci 1 1:2433-2442.

Morrissey TK, Kleitman N, Bunge RP (199lb) Functional characteristics of adult derived rat, monkey, and human SCs studied in vitro. Soc Neurosci Abstr 17:376.

Nadim W, Anderson PN, Woodham P, Turmaine M (1988) Axonal regeneration through long freeze-dried nerve grafts. J Anat 158:216.

Olivera A, Spiegel S (1993) Sphingosine-1-phosphate as second messenger in cell proliferation induced by PDGF and FCS mitogens. Nature 365:557-560.

Paino CL, Bunge M (1991) Induction of axonal growth into Schwann cell implants grafted into lesioned adult rat spinal cord. Exp Neurol 114:254-257.

Pastan I, Johnson GS, Anderson WB (1975) Role of cyclic nucleotides in growth control. Annu Rev Biochem 44:491-522.

Peles E, Ben-Levy R, Tzahar E, Liu N, Wen D, Yarden Y (1993) Celltype specific interactions of Neu differentiation factor (NDF/heregulin) with Neu/HER-2 suggests complex ligand-receptor relationships. EMBO J 12:961-971.

Pellegrino RG, Politis MJ, Ritchie JM, Spencer PS (1986) Events in degenerating cat peripheral nerve: induction of Schwann cell $\mathrm{S}$ phase and its relation to nerve fiber degeneration. J Neurocytol 15:17-28.

Pleasure D, Kreider B, Sobue G, Ross AH, Koprowski H, Sonnenfeld KH, Rubenstein AE (1986) Schwann-like cells cultured from human dermal neurofibromas. Ann NY Acad Sci 486:227-240.

Plowman GD, Whitney GS, Neubauer MG, Green JM, McDonald VL, Todaro GL, Shoyab M (1990) Molccular cloning and expression of an additional epidermal growth factor receptor-related gene. Proc Natl Acad Sci USA 87:4905-4909.

Plowman GD, Culouscou J-M, Whitney GS, Green JM, Carlton GW, Foy L, Neubauer MG, Shoyab M (1993a) Ligand specific activation of HER4/p180 erbB4, a fourth member of the epidermal growth factor receptor family. Proc Natl Acad Sci USA 90:1746-1750.

Plowman GD, Green JM, Culouscou J-M, Carlton GW, Rothwell VM, Buckley $S$ (1993b) Heregulin induces tyrosine phosphorylation of HER4/p180 erb84. Nature 366:473-475.

Porter S, Clark MB, Glaser L, Bunge RP (1986) Schwann cells stimulated to proliferate in the absence of neurons retain full functional capacity. J Neurosci 6:3070-3078.

Raff MC, Abney E, Brockes JP, Hornby-Smith A (1978a) Schwann cell growth factors. Ccll 15:813-822.

Raff MC, Hornby-Smith A, Brockes JP (1978b) Cyclic AMP as a mitogenic signal for cultured rat Schwann cells. Nature 273:672-673.

Ridley AJ, Davis JB, Stroobant P, Land H (1989) Transforming growth factors- $\beta 1$ and $\beta 2$ are mitogens for rat Schwann cells. J Cell Biol 109: $3419-3424$.

Rutkowski JL, Tennekoon GI, McGillicuddy JE (1992) Selective culture of mitotically active human Schwann cells from adult sural nerves. Ann Neurol 31:580-586.

Sager R (1989) Resistance of human cells to oncogenic transformation. Cancer Cells 2:487-493.

Schubert D (1992) Synergistic interactions between transforming growth factor and fibroblast growth factor regulate Schwann cell mitosis. J Neurobiol 23:143-148.

Slamon DJ, Clark GM, Wong SG, Levin WJ, Ullrich A, McGuire WL (1987) Human breast cancer: correlation of relapse and survival with amplification of the HER-2/neu oncogene. Science 235:177-182.

Sliwkowski MX, Schaefer G, Akita RW, Fitzpatrick D, Lofgren J, Nuijens A, Fendly BM, Cerione RA, Vandlen RL, Carraway KL III (1994) Coexpression of erbB2 and erbB3 proteins reconstitutes a high affinity receptor for heregulin. J Biol Chem 269:14661-14665.

Usdin TB, Fischbach GD (1986) Purification and characterization of a polypeptide from chick brain that promotes the accumulation of acetylcholine receptors in chick myotubes. J Cell Biol 103:493-507.

Weinmaster G, Lemke G (1990) Cell-specific cyclic AMP-mediated induction of the PDGF receptor. EMBO J 9:915-920.

Wen D, Peles E, Cupples R, Suggs SV, Bacus SS, Luo Y, Trail G, Hu S, Silbiger SM, Levy RB, Koski RA, Lu HS, Yarden Y (1992) Neu differentiation factor: a transmembranc glycoprotein containing an EGF domain and an immunoglobulin homology unit. Cell 69:559572.

Zimmer C, Le Dourain N (1993) Neural crest lineage. In: Peripheral neuropathy, 3d ed (Dyck PJ, Thomas PK, Griffin JW, Low PA, Poduslo JF, eds), pp 299-316. Philadelphia: Saunders. 